\title{
Morphological Variation of Pelodytes caucasicus Boulenger, 1896 (Anura: Pelodytidae) from Turkey ${ }^{[*]}$
}

\author{
Tuğba ERGÜL KALAYCI ${ }^{1 *}$ Kafiye GÜMÜŞSOY ${ }^{1}$ Çiğdem GÜL ${ }^{2}$ \\ ${ }^{I}$ Recep Tayyip Erdoğan University, Faculty of Arts and Sciences, Department of Biology, Rize, Turkey \\ ${ }^{2}$ Department of Biology, Faculty of Arts and Sciences, Çanakkale Onsekiz Mart University, Çanakkale, Turkey
}

How to cite: Ergül Kalaycı, T., Gümüşsoy, K. \& Gül, Ç. (2021). Morphological Variation of Pelodytes caucasicus Boulenger, 1896 (Anura: Pelodytidae) from Turkey. J. Anatolian Env. and Anim. Sciences, 6(4), 712-716.

Atıf yapmak için: Ergül Kalaycı, T., Gümüşsoy, K. \& Gül, Ç. (2021). Türkiye'deki Pelodytes caucasicus Boulenger, 1896 (Anura: Pelodytidae) Türünün Morfolojik Çeşitliliği. Anadolu Çev. ve Hay. Dergisi, 6(4), 712-716.

(iD: https://orcid.org/0000-0002-4790-0263

(D): https://orcid.org/0000-0002-6700-7480

(iD: https://orcid.org/0000-0003-4736-2677

*Corresponding author:

Tuğba ERGÜL KALAYCI

Recep Tayyip Erdoğan University, Faculty of Art and Science, Department of Biolog, Rize, Türkiye

凶: tugba.ergul@erdogan.edu.tr

\begin{abstract}
The Parsley frog is represented by a single species from Anatolia which is called Pelodytes caucasicus. This species is categorized as a near threatened in the conservation list and has very limited distribution along the North East Black Sea and its populations have been poorly studied. In this study, we analyzed morphological variation of 59 specimens from different localities from Anatolia (Artvin; Karagöl, Rize; Çat and Trabzon; Hıdırnebi) unraveling the morphological differences among $P$. caucasicus populations. For this purpose, we used multivariate analysis such as principal component analysis (PCA) and linear discriminant analysis (LDA). Although there was considerable an overlap among morphological variation of localities according to PCA analysis, slight differences were observed in LDA analyses. In PCA analysis, the Head Width (HW), Head length (HL), and Snout vent length (SVL) are primarily discriminating characters for $P$. caucasicus. In LDA analysis, the NL, HW, and HL are primarily discriminating characters. This study will contribute to the limited data of $P$. caucasicus and enlarge the knowledge of geographic variation for P. caucasicus in Anatolia.
\end{abstract}

Keywords: Caucasian, morphometric differences, P. caucasicus, Turkey.

\section{Türkiye'deki Pelodytes caucasicus Boulenger, 1896 (Anura: Pelodytidae) Türünün Morfolojik Çeşitliliği}

\section{*Sorumlu yazar:}

Tuğba ERGÜL KALAYCI

${ }^{1}$ Recep Tayyip Erdoğan Üniversitesi, Fen

Edebiyat Fakultesi, Biyoloji Bölümü, Rize, Turkey

凶: tugba.ergul@erdogan.edu.tr

\begin{abstract}
Öz: Anadolu'da Pelodytidae familyasının Parsley kurbağası Pelodytes caucasicus adı ile bilinen tek türü dağılış göstermektedir. Bu tür koruma listelerine tehdite açık olarak kategorize edilir.Doğu Karadeniz boyunca kısıtlı yayılıma sahiptir ve populasyonları az çalışılmıştır. Bu çalışmada Anadolu'daki (Artvin; Karagöl, Rize; Çat ve Trabzon; Hıdırnebi) P. caucasicus populasyonları arasındaki morfolojik farklılıkları ortaya çıkarmak için 59 bireyin morfolojik çeşitliliği analiz edilmiştir. Bu amaç doğrultusunda temel bileşenler analizi (PCA) ve doğrusal ayırım analizi (LDA) gibi çoklu analizler kullanılmıştır. Temel bileşenler analizinde lokaliteler arası çakışmalar gözüksede doğrusal ayırım analizinde az da olsa farklllık gözlenmiştir. Temel bileşenler analizine göre Baş Genişliği (HW), Baş Uzunluğu (HL) ve Burun Ucu-Kloak Arası Mesafe (SVL) öncül ayırıcı karakterlerdir. Doğrusal ayırım analizine göre NL, HW ve HL öncül ayırıcı karakterlerdir. Bu çalışma $P$. caucasicus'un kısıtlı verisine katkı sağlamış ve türün coğrafik varyasyonu ile ilgili bilgiyi genişletmiştir.
\end{abstract}

Anahtar kelimeler: Kafkasya, morfolojik farkll1ıklar, P. caucasicus, Türkiye.

\section{INTRODUCTION}

The Pelodytidae family is represented by one genus (Pelodytes) and four species overall its distribution areas. Three of species of Pelodytes (P. atlanticus, $P$. ibericus, $P$. punctatus) inhabited in Iberian Peninsula and

${ }^{\left[{ }^{*}\right]}$ This study was produced from the master thesis. around France and one of them ( $P$. caucasicus) inhabited to Caucasian region.

Pelodytes caucasicus, is an endemic species of the Caucasian Isthmus, the region delimiting Europe and Asia, and lying between the Black Sea in the west and the 
Caspian Sea in the east (Litvinchuk \& Kidov, 2018). This species is distributed in the western Republic of Georgia, Krasnodar Region of Russia, and extreme northeastern Turkey, along with isolated populations in the central part of Turkey's northern coast and Georgia-Azerbaijan border area (Kaya et al., 2009). Caucasian Parsley frog ( $P$. caucasicus) is characterized by fragmented populations, and little information about its population's features exists. Above all, $P$. caucasicus is cataloged as Near Threatened (NT) in the International Union for Conservation of Nature (IUCN) Red List of Threatened Species.

Body size is a fundamental morphological trait and important in a physiological, ecological, and behavioral context of a species (Schäuble, 2004). The population of species that inhabit a wide range of environments frequently displays divergent morphologies that correlate with differences in ecological parameters (Rivera, 2008). Despite that, in some situations morphological differentiation of amphibians can be very small and involves mainly differences in body proportions (Babik \& Rafinski, 2000).

Comparative studies are pivotal for expanding awareness about the current situation of populations and tender differences among populations and for explaining the reason for the effects of different factors on populations. Previously, some works have been carried out on distribution, ecology, breeding, age structure, helminth parasites, hematology, morphology, and serology of $P$. caucasicus in Turkey (Steiner, 1968; Franzen, 1999; Arıkan et al., 2003; Tosunoğlu \& Taşkavak 2004; Arıkan et al., 2007; Erişmiş et al., 2009, Yıldırımhan et al., 2009, Litvinchuk \& Kidov, 2018). Limited studies are existing about morphological characters of $P$. caucasicus through its distribution area, especially in Turkey. In addition to that, newly introduced areas are involved in literature in Turkey. Thus far, possible morphological separation during species evolution remains completely unknown.

In this study, we determined whether morphological characters differ significantly from one locality to another and characterized these differences for $P$. caucasicus. Body differences were analyzed using multivariate methods such as principal component analysis (PCA) and linear discriminant analysis (LDA). Specimens of three different populations from Artvin, Rize, and Trabzon were evaluated according to morphological variation according to PCA and LDA for the first time in literature

\section{MATERIAL AND METHOD}

Morphological data were obtained from 59 specimens from 3 different localities Karagöl; Artvin (latitude/longitude: 41.38; 41.85) $(16 \hat{\jmath}, 2$ \%), Çat; Rize (latitude/longitude: 40.86; 40.94) (21ð, 1 \%) and Hidırnebi; Trabzon (latitude/longitude: 40.96; 39.43) $(17 \widehat{\gamma}, 2$ 우 throughout the Eastern Black Sea region of Turkey (Figure 1). The morphological measurement was taken with the permission of the local ethics committee of Çanakkale Onsekiz Mart University for animal experiments (approval reference number: 2019/09). No specimens were taken to the laboratory. All measurements were taken in the field.
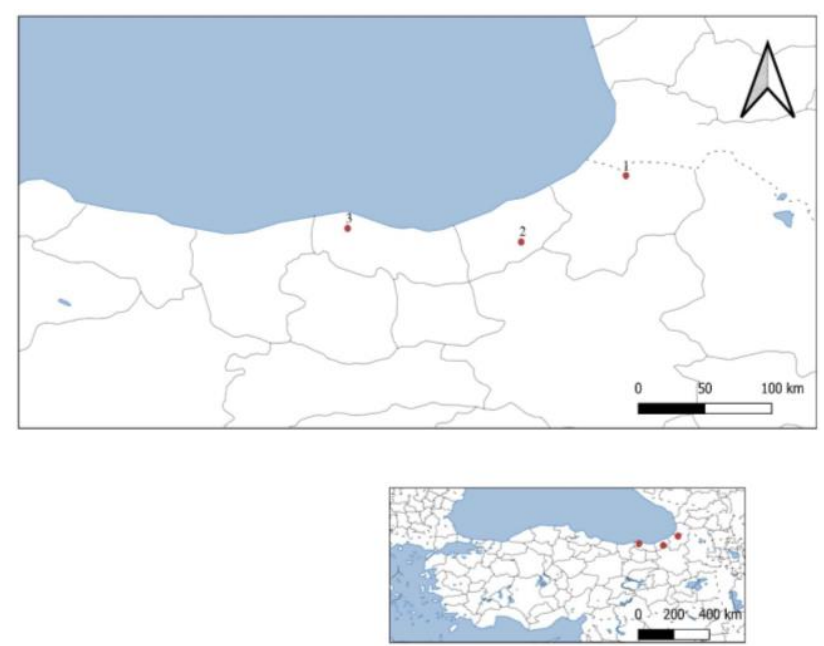

Figure 1. Map of sampling localities (1: Karagöl; Artvin, 2: Çat; Rize and 3: Hidırnebi; Trabzon.

We sampled specimens in July 2020 and July 2021 in their activation time. Sex determination was performed by the absence or presence of the appearance of black tubercles, especially on the venter during the breeding season in males. In advance of measurement, all specimens were anesthetized and all individuals were measured at one time. Using a digital caliper to the nearest $0.1 \mathrm{~mm}$, we measured the following six morphological characters: snout-vent length (SVL), head length (HL), head width (HW), Nostril length (NL), femur length (FL), tibia length (TL). To minimize bias introduced by measurements and avoid extraneous error quantification of body dimensions, all frogs were collected by a single observer (T. Ergül Kalayc1).

Because we had insufficient data for female individuals, we analyzed pool data for each location (females and males were not separately analyzed). We used principal components analysis (PCA) to find the best lowdimensional representation of variation in the data to determine whether morphological variation could form the basis of detectable group structure. We used Linear Discriminant analysis for specified morphological clustering. The function "prcomp" with "scale = TRUE" was used for the principal component analyses, clustering individuals in the multivariate space of the first two principal components ( $\mathrm{PC1}$ and $\mathrm{PC} 2)$; and the function "lda" in package "MASS" (Venables \& Ripley, 2002) was used for the linear discriminant analysis. Statistical 
analysis was performed using the $\mathrm{R}$ ( $\mathrm{R}$ Development Core Team, 2021).

\section{RESULTS}

The mean values for SVL, HL, HW, NL, FL and TL were found as 49.60, 15.69, 15.09, 3.38, 23.12 and $25.73 \mathrm{~mm}$ for Artvin, respectively. For Rize, we found 43.38, 15.11, 13.83, 4.26, 19.38, and $21.58 \mathrm{~mm}$ for SVL, HL, HW, NL, FL and TL, respectively. The mean values for SVL, HL, HW, NL, FL and TL were found as 49.76, 16.12, 16.94, 3.43, 19.83, and $21.97 \mathrm{~mm}$ for Trabzon, respectively.

There is no clear separation for P. caucasicus individual from three localities (Artvin, Rize, and Trabzon). We retained the first two components for the principal component analysis (PCA). These two components explained $73.51 \%$ of the morphological variation. The factor loadings for the first PC were all positive, with the heaviest loadings on SVL and HL. The loadings of the second $\mathrm{PC}$ were weighted heavily positive for SVL, HL, and HW, and negatively for NL, FL, and TL (Table 1).

Table 1. PCA loadings for P. caucasicus. snout-vent length (SVL), head length (HL), head width (HW), Nostril length (NL) femur length (FL), tibia length (TL).

\begin{tabular}{lcccccc}
\hline & PC1 & PC2 & PC3 & PC4 & PC5 & PC6 \\
\hline SVL & 0.444 & 0.123 & 0.332 & -0.811 & -0.139 & -0.026 \\
HL & 0.463 & 0.402 & -0.118 & 0.371 & -0.654 & 0.213 \\
HW & 0.431 & 0.511 & 0.068 & 0.233 & 0.673 & -0.205 \\
NL & 0.187 & -0.038 & -0.929 & -0.299 & 0.096 & -0.035 \\
FL & 0.422 & -0.543 & 0.049 & 0.214 & -0.143 & -0.677 \\
TL & 0.437 & -0.516 & 0.071 & 0.123 & 0.267 & 0.672 \\
\hline
\end{tabular}

The continuous variables presented high correlation values for the first component except for NL (Table 2).

Table 2. Correlation of variables with $\mathrm{PC} 1$ and $\mathrm{PC} 2$ explained for $P$. caucasicus (geographic location as a factor).

\begin{tabular}{lcc}
\hline Variable & PC1 & PC2 \\
\hline SVL & 0.786 & 0.139 \\
HL & 0.819 & 0.455 \\
HW & 0.763 & 0.577 \\
NL & 0.330 & -0.043 \\
FL & 0.747 & -0.613 \\
TL & 0.773 & -0.583 \\
\hline
\end{tabular}

The most important character contributing to PC1 was the snout-vent length (SVL). PC2 was positively correlated with SVL, HL, and HW and negatively correlated with NL, FL, and TL. The graphical representation of $\mathrm{PC} 1 / \mathrm{PC} 2$ showed an overlap for three distribution area members (Figure 2). Although, Trabzon and Artvin showed no clear separation from Rize, specimens from Rize could be separated by their smaller size (Figure 2).

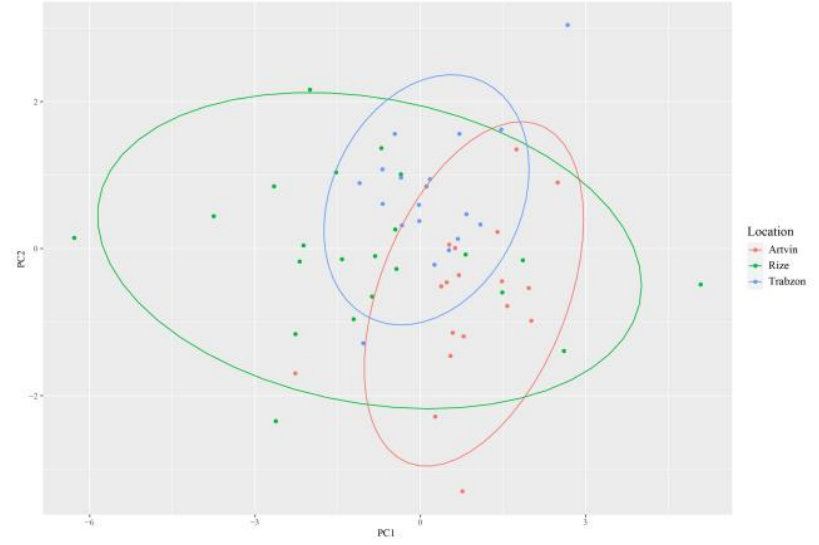

Figure 2. Ordination of the first and second principal components for $P$. caucasicus (Red dots represent Artvin individuals and green dots represent Rize individuals, while blue dots represent Trabzon individuals).

The results from PCA suggested that we could find the best separation of groups by employing LDA. The prior probabilities of the linear discriminant analysis (LDA) among localities were as follows: Artvin (0.28), Trabzon (0.28) and Rize (0.43). LDA analysis showed the function 1 explained $76.2 \%$ of the variance whereas function 2 explained $23.8 \%$ of the variance (Figure 3 ).

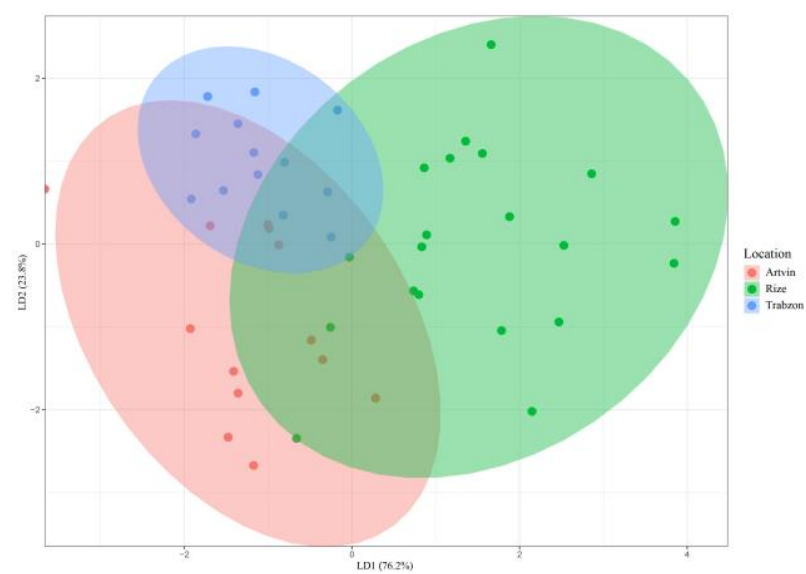

Figure 3. Plot of linear discriminant axis 1 versus linear discriminant axis 2 from morphometric characters of $P$. caucasicus specimens.

Artvin had the higher error rate in specimen classification (4 of 18 individuals, error $=22.22 \%$ ) followed by Rize ( 2 of 22 individuals, error $=9.09 \%$ ) and Trabzon ( 1 of 19 individuals, error $=5.26 \%$ ). A total of $\%$ 89.83 correct classification was achieved in LDA analysis. Differentiation along the LD1 is driven by the number of NL, HL, and HW (Table 3). The LD2 is driven primarily by HW and HL (Table 3 ).

Table 3. Coefficients of linear discriminant.

\begin{tabular}{lcc}
\hline Variables & LD1 & LD2 \\
\hline SVL & -0.187 & 0.009 \\
HL & 0.281 & -0.271 \\
HW & -0.274 & 0.498 \\
NL & 0.927 & 0.188 \\
FL & -0.187 & -0.026 \\
TL & 0.025 & -0.286 \\
\hline
\end{tabular}




\section{DISCUSSION}

This is the first study to compare the morphological features of $P$. caucasicus from Artvin (Karagöl), Rize (Çat village), and Trabzon (Hıdırnebi plateau) localities. Though P. caucasicus is distributed to restricted areas along with Caucasian and categorized as threated species in different conservation lists, there is limited data available for morphological comparison of Caucasian Parsley frog from Anatolia. Although morphometric for female individuals is missing, due to the lack of production of advertisement signals and the difficulty of sampling, this study gathers new information about $P$. caucasicus, which is highly required for this under-studied and near threated species.

Tosunoğlu and Taşkavak (2004) previously compared the specimen from Trabzon (Uzungöl) and Rize (Çamlıhemşin) and found that two populations are similar according to the coefficient of difference values. Their results also resembled the populations from Georgia and Caucasus (Tarkhnishvili \& Gökhelashvili, 1999). As Franzen (1999) specified the eastern Black Sea populations of Turkey do not differ morphologically from the neighbor populations. The study of Tosunoğlu \& Taşkavak (2004) was the only study existing in the literature about the morphological comparison of $P$. caucasicus from Anatolia. According to our study, Rize specimen slightly differed from Trabzon in particular LDA analysis.

Comparison between two analyses showed that LDA provided higher resolution than PCA. In PCA analysis, three populations were completely intermixed with each other. But in LDA analysis, Rize specimens proneness to Artvin and Trabzon specimens disappeared.

It is essential to recognize characters that differentiate populations from morphologically distinguished populations. In this study, we found that SVL, HL, and HW are primarily distinguishable characters for $P$. caucasicus in PCA analysis. In terms of LDA analysis, NL, HW, and $\mathrm{HL}$ are primarily discriminated values for $P$. caucasicus.

The specimens from Rize differed from their narrow head size from Trabzon and Artvin. Former studies have indicated anurans co-occurring with predators to exhibit a narrower head compared to inhabiting predatorfree environments (Tejedo et al., 2010). Rize specimens that experience greater predation pressure should exhibit a narrower head. Also, the habitat of Rize specimens tends to dry compared to Artvin and Trabzon. Destruction of water bodies will limit the food resources and amphibians will not be able to find appropriate places for reproduction. Eventually, this will restrain the body proportions.

Geographic variation in body size of anurans could result from either phenotypic plasticity or adaptation to particular environments (Rivas et al., 2018). It is vital to the understanding interplay of morphological variation to understand how species survive across different landscapes (Shaffer et al., 2015). P. caucasicus is near threated species and its population is seriously threatened by habitat changes. The conclusions of this study give us a chance to look through the $P$. caucasicus's life history attributes and see whether morphology is changing in different habitats in the current state. Further research for P. caucasicus inclusive more variables will contribute to the literature.

\section{ACKNOWLEDGEMENTS}

We would like to thank Recep Tayyip Erdoğan University for financially supporting this study (Project Number: FYL-2020-1076).

\section{REFERENCES}

Arikan, H., Atatür, M.K. \& Tosunoğlu, M. (2003). A study on the blood cells of the Caucasus Frog, Pelodytes caucasicus. Zoology in the Middle East, 30(1), 43-47.

Arıkan, H., Tosunoğlu, M., Atatür, M.K. \& Göçmen, B. (2007). Some Comments of the Breeding Biology of Pelodytes caucasicus Boulenger, 1896 (Anura: Pelodytidae) from Uzungöl, Northeast Anatolia. Turkish Journal of Zoology, 31, 53-64.

Babik, W. \& Rafiński, J. (2000). Morphometric differentiation of the moor frog (Rana arvalis Nilss.) in Central Europe. Journal of Zoological Systematics and Evolutionary Research, 38(4), 239-247.

Erişmiş, U.C., Arıkan, H., Konuk, M. \& Guarino, F.M. (2009). Age Structure and Growth in Caucasian Parsley Frog Pelodytes caucasicus (Boulenger, 1896) from Turkey. Russian Journal of Herpetology, 16(1), 19-26.

Franzen, M. (1999). Verbreitung und Ökologie von Pelodytes caucasicus Boulenger, 1896 in der Türkei (Distribution and Ecology of Pelodytes caucasicus Boulenger, 1896 in Turkey). Salamandra, 35(1), 1-18.

Kaya, U., Tuniyev, B., Tuniyev, S., Kuzmin, S., Tarkhnishvili, D., Tuniyev, B., Papaenfuss, T., Sparreboom, M., Ugurtas, I., Anderson, S., Eken, G., Kiliç, T. \& Gem, E. (2009). Pelodytes caucasicus. The IUCN Red List of Threatened Species 2009: International Union for Conservation of Nature. http://www.IUCN.org. International Union for the Conservation of Nature (IUCN). 2021. IUCN Red List of Threatened Species, 2021

Litvinchuk, S.N. \&. Kidov, A.A. (2018). Distribution and conservation status of the Caucasian parsley frog, Pelodytes caucasicus (Amphibia: Anura). Nature Conservation Research, 3(S1), 51-60. 
R Core Team. (2021). R: a language and environment for statistical computing. Vienna: R Foundation for Statistical Computing

Rivas, J., Quiero, A., Penna, M. \& Velásquez, N. A. (2018). Body-size variation across environmental gradients in an ectothermic organism: An intraspecific approach to ecogeographic patterns. Herpetologica, 74(3), 191-198.

Rivera, G. (2008). Ecomorphological variation in shell shape of the freshwater turtle Pseudemys concinna inhabiting different aquatic flow regimes. Integrative and Comparative Biology, 48(6), 769-787.

Shaffer, H. B., Gidiş, M., McCartney-Melstad, E., Neal, K. M., Oyamaguchi, H. M., Tellez, M., \& Toffelmier, E. M. (2015). Conservation genetics and genomics of amphibians and reptiles. Annual Review of Animal Bioscience., 3(ch_1), 113-138.

Schäuble, C. S. (2004). Variation in body size and sexual dimorphism across geographical and environmental space in the frogs Limnodynastes tasmaniensis and L. peronii. Biological Journal of the Linnean Society, 82(1), 39-56.

Steiner, H.M. (1968). Pelodytes caucasicus Boulenger 1896 (Pelobatidae, Amphibia) in der Türkei. Annalen des Naturhistorischen Museums in Wien, 291-298.

Tarkhnishvili, D.N. \& Gökhelashvili, R.K. (1999). The Amphibians of the Caucasus. Advances in Amphibian Researc in the Former Soviet Union Sofia-Moscow, 4, 94-106.

Tejedo, M., Marangoni, F., Pertoldi, C., Richter-Boix, A., Laurila, A., Orizaola, G., Nicieza, A.G., Álvarez, D. \& Gomez-Mestre, I. (2010). Contrasting effects of environmental factors during larval stage on morphological plasticity in post-metamorphic frogs. Climate Research, 43(12), 31-39.

Tosunoğlu, M. \& Taşkavak, E. (2004). A Preliminary Study on Morphology and Serology of Pelodytes caucasicus Boulenger 1896 Populations From NorthEastern Turkey. Pakistan Journal of Biological Sciences, 7(7), 1186-1190.

Venables, W.N. \& Ripley, B.D. (2002). Modern Applied Statistics with $S$. Fourth Edition. Springer, NewYork, 505 p.

Yildirimhan, H.S., Bursey, C.R. \& Goldberg, S.R. (2009). Helminth parasites of the Caucasian parsley frog, Pelodytes caucasicus, from Turkey Comparative Parasitology, 76(2), 247-257. 